\title{
IMPLEMENTASI PENDEKATAN PEMBELAJARAN BERBASIS STUDENT CENTERED LEARNING
}

\author{
Febrian Alwan Bahrudin \\ Dosen Program Studi PPKn FKIP Universitas Sultan Ageng Tirtayasa \\ Serang, Indonesia \\ febrian_alwan24@yahoo.com
}

\begin{abstract}
This research is about the Learning Implementation using The 'Student Centered Learning' Base in the Pancasila and Citizenship Education Department, the learning process activity can be divided into two types of approaches, such as the learning approach with 'Teacher Centered Learning' (TCL) base, and with the 'Student Centered Learning' (SCL) base. The approach of learning using the 'Teacher Centered Learning'(TCL) base is an activity in which the lecturer becomes the main subject in the process of learning, and within the learning process using the 'Teacher Centered Learning' (TCL) the lecturer will be a lot more active than the students and thus have a much more important role in this method when it comes to giving the materials for learning. In the 'Teacher Centered Learning' (TCL) base method, students tend to be much less active in the learning process, whereas the 'Student Centered Learning' (SCL) is a method that gives the students the chance to be active in the process, or in this case, the students are now the main subject of the learning process. The approach of this research is based on qualitative approach and also using descriptive study method. The implementation of learning using the 'Student Centered Learning' (SCL) is done through several stages, beginning with planning, execution, and ends with evaluation. In the planning stage the lecturer prepares the administrative part of learning, in which includes making lesson plan, and preparing things that support the learning process, such as media, learning resources, or other innovations that supports learning. This stage of the learning process aims to determine the initial steps so that the learning process can run effectively and efficiently, the making of the lesson plan which positions the students to have a much more dominant role than lecturers is a form of learning using the 'Student Centered Learning' (SCL) method, in this stage the implementation of learning makes the students take more part in the learning process compared to lecturers, students are required to be active and creative in the learning process, in this activity the use of learning media is very helpful to be able to implement student centered learning. Student's active role can be applied through class presentations about the material being discussed, besides that the use of electronic-based learning or e-learning has been applied in the Department of Pancasila and Citizenship Education. The last stage is the closing stage where the usual thing to do is to reflect on the learning that has been done with the intent to evaluate so students and lecturers can determine learning improvements at the next meeting.
\end{abstract}

Keywords : Studen Centered Learning

\section{PENDAHULUAN}

Pendidikan merupakan suatu cara untuk dimana kualitas sumber daya manusia disuatu membangun kualiatas sumber daya manusia, negara, untuk dapat membentuk kualiatas dari pendidikan itu sendiri dapat menentukan sumberdaya manusia yang unggul melalui 
pendidikan dapat diimplementasikan dalam proses pembelajaran, ketika proses pembelajaran berjalan dengan baik maka diharapkan kompetensi yang ingin dicapai dapat terlaksana. Proses pembelajaran di perguruan tinggi adalah suatu proses interaksi yang melibatkan dosen dengan mahasiswa untuk mencapai tujuan belajar berdasarkan perencanaan pembelajaran yang telah dibuat, hal ini sebagai mana terdapat dalam UndangUndang Sistem Pendidikan Nasional Nomor 20 tahun 2003 menyatakan bahwa "Pembelajaran adalah proses interaksi peserta didik dengan pendidik dan sumber belajar pada suatu lingkungan belajar". Berdasarkan hal tersebut pembelajaran melibatkan interaksi antara dosen dengan mahasiswanya dalam suatu kegitan di lingkungan belajar dengan maksud untuk mencapai tujuan kompetensi pembelajaran, tahapan proses pembelajaran secara umum terdiri dari kegiatan pendahuluan, kegitan inti, dan kegitan penutup, setiap tahapan tersebut harus dapat ditempuh secara sitematis, efektif dan efisien, utuk dapat mencapai kompetensi tujuan belajar yang diinginkan.

Penerapan proses pembelajaran di Indonesia yang diterapakan oleh soerang dosen masih banyak yang menerapakan pola pembelajaran yang cenderung konvensional yang menempatkan dosen menjadi sentral atau pusat dalam proses pembelajaran dan sekaligus menjadikan mahasiswa menjadi objek dan subjek pembelajaran, selain itu pola pembelajaran yang cendrung konvensional menyamaratakan kemampuan setiap individu mahasiswa, pada dasarnya setiap individu memiliki kemampuan yang tidak bisa disama ratakan sehingga kompetensi yang ingin diterima oleh setiap individu mahasiswa tidak bisa didapat secara menyeluruh, untuk mengatasi hal tersebut diperlukan proses pembelajaran atau perkuliahan yang dapat memaksimalkan potensi kompetensi dalam diri mahasiswa.

Proses pembelajaran atau perkuliahan di dalam kelas yang dilakukan oleh dosen dapat menerapkan pendekatan pembelajaran yang berpusat di dosen atau dapat juga pembelajaran yang berpusat di mahasiswa, model pembelajaran konvensional mahasiswa cenderung bersifat kurang aktif dalam proses pembelajaran, kondisi seperti ini dapat dikatakan tidak dapat memberdayakan mahasiswa untuk mampu mengembangkan belajarnya melalui peningkatan interaksi dengan lingkungan belajarnya, sehingga mahasiswa tidak akan mampu memaksimalkan pemahaman dan pengetahuan di lingkungan sekitarnya, berdasarkan hal tersebut diperlukan pengembangan pendekatan pembelajaran yang lebih menarik dan membuat mahasiswa aktif di proses pembelajaran sehingga potensi ataupun kompetensi mahasiswa dapat dicapai semaksimal mungkin.

Dalam pembelajaran terdapat pendekatan pembelajaran, strategi pembelajaran, metode 
pembelajaran, dan teknik pembelajaran, hal tersebut digunakan untuk mempermudah kegiatan proses pembelajaran, selain itu pendekatan pembelajaran juga dapat diartikan sebagai suatu tolak ukur atau sudut pandang dosen dalam mengajar dengan tujuan untuk memaksimalkan kompetensi pembelajaran yang ingin dicapai.

Kegiatan proses pembelajaran dapat terbagi atas dua tipe pendekatan pembelajaran yaitu, pendekatan pembelajaran berbasis Teacher Centered Learning (TCL) dan pendekatan pembelajaran berbasis Student Centered Learning (SCL). Pendekatan pembelajaran berbasis Teacher Centered Learning (TCL) yaitu suatu kegiatan pembelajaran dimana seorang dosen menjadi subjek utama dalam proses pembelajaran dan dalam proses pembelajaran yang menggunakan pendekatan Teacher Centered Learning (TCL) ini seorang dosen akan lebih aktif dibandingkan mahasiswanya, dosen memiliki peran penting untuk penyampaian materi dan biasanya dalam pendekatan pembelajaran Teacher Centered Learning TCL ini mahasiswa cenderung lebih tidak begitu aktif dalam proses pembelajaran, sedangkan, pendekatan pembelajaran berbasis Student Centered Learning (SCL) yaitu suatu pendekatan yang memberikan mahasiswanya untuk berperan aktif dalam proses pembelajaran atau mahasiswa dijadikan subjek utama dalam poses pembelajaran, hal ini sebagaimana dikemukakan oleh Hesson (2007:628) yang menyatakan bahwa Student Centered Learning (SCL)"model is teaching integrative thinking, based on existing models of creativity and synthesis. In this model, the student is put at the heart of a bigger learning process that includes instructors, specialists and the public".

Dapat ditarik suatu kesimpulan bahwa Student Centered Learning (SCL)merupaka pembelajaran yang integratif yang menekankan kreativitas dan biasanya dalam proses pembelajaran yang menggunakan pendekatan Student Centered Learning (SCL) ini menuntut untuk mahasiswanya aktif dan mandiri dalam mencari materi, hal ini sebagimana dikemukakan oleh Natawijaya dalam Depdiknas (2005:31) yang menyatakan bahwa "pembelajaran yang aktif yaitu merupakan suatu sistem pembelajaran yang mengedepankan keaktifan siswa baik secara fisik, metal, intelektual dan emosional dengan tujuan memperoleh hasil belajar yang memadukan aspek kognitif, afektif dan psikomotor".

Berdasarkan hal tersebut diperlukanlah proses pembelajaran yang memungkinkan dikembangkannya keaktifan setiap mahasiswa yaitu dengan menggunakan pedekatan pembelajaran yang berpusat di mahasiswa Student Centered Learning (SCL), dalam pendekatan berbasis Student Centered Learning (SCL) ini mahasiswa dapat mengembangkan kreatifitasnya tanpa 
batas, serta mahasiswa dapat memanfaatkan bahan ajar, suatu media atau teknologi untuk memperoleh suatu pengetahuan dan mahasiswa dapat menentukan gaya belajarnya sendiri dalam mencari atau memperoleh suatu pengetahuan, dalam pendekatan berbasis Student Centered Learning (SCL) mahasiswa dituntut juga untuk mengembangkan karakternya yang berkaitan dengan belajarnya.

Salah satu jurusan yang sudah dapat menerapkan pendekatan pembelajaran yang berpusat di mahasiswa adalah jurusan Pendidikan Pancasila dan Kewarganegaraan berdasarkan hal tersebut peneliti tertarik untuk dapat mendeskripsikan bagaimana implementasi pembelajaran berbasis Student Centered Learning (SCL).(Studi Deskriptif di Jurusan Pendidikan Pancsila dan Kewarganegaraan Fakultas Keguruan dan Ilmu Pendidikan Universitas Sultan Ageng Tirtayas).

\section{METODE PENELITIAN}

Pendekatan penelitian merupakan tata cara atau langkah-langah berdasarkan tata urutan tertentu dengan tujuan mencapai pengetahuan yang sesuai dengan nilai-nilai yang ditemukan berdasarkan hasil penelitian, sedangkan metode penelitian adalah suatu cara dengan tujuan dapat mengumpulkan, menyusun, dan menganalisis data berdasarkan kajian masalah yang menjadi objek peneltian.
Pengunaan pendekatan penelitian yang digunakan dalam penelitian ini menggunakan pendekatan penelitian secara kualitatif, hal ini dikarenakan peneliti igin memahami apa yang dialami terdap subjek penelitian, hal ini sebagaimana pendapat, Lexy J. Moleong dalam bukunya metode pendekatan kualitatif (2005:6), mengemukakan bahwa "Penelitian kualitatif adalah penelitian yang bermaksud untuk memahami fenomena tentang apa yang dialami oleh subjek penelitian misalnya perilaku, persepsi, tindakan, secara holistik dan dengan cara deskriptif”.

Berdasarkan pendapat di atas dapat diambil kesimpulan bahwa pendekatan penelitian secara kualitatif ini memiliki tujuan memahami keadaan yang dialami oleh subjek penelitian itu sendiri, dalam penelitian pendekatan kualitatif ini sangatlah tergantung terhadap analisis berdasarkan data penelitian, objektivitas pelitian, sistematik penelitian, dan ketepatan hasil dari interprestasi seorang peneliti itu sendiri. Berdasaran hal tersebut peneliti mengambil suatu kesimpulan bahwa diambilnya pendakatan penelitian secara kualitatif ini didasari atas dasar permasalahan yang ada dalam penelitian ini sangatlah membutuhkan data-data yang ada dilapangan berdasarkan data konstektual dan aktual dengan tujuan menjamin data itu tidaklah usang, selanjutnya peneliti mengambil kesimpulan bahwa dasar dipilihnya pendekatan secara kualitatif ini membutuhkan data primer berdasarkan 
subjek penelitian sesuai dengan data yang ada di lapangan.

Peneliti beralasan pemelihan pendekatan kualitatif ini dasarkan oleh dua alasan yang mendasar, alasan pertama penelitian ini membutuhkan data-data lapangan yang aktual dan konstektual, alasan ke dua bagaimana keterkaitan data-data masalah dengan data primer yang didasarkan dari subjek penelitian.

Selaian menggunakan pendekatan penelitian peneliti juga menggunakan metode penelitaian, metode penelitian bertujuan untuk dapat mengetahui tujuan berdasarkan hasil penelitian itu sendiri, sehingga diharapkan data penelitian yang peneliti lakukan mendapatkan hasil data yang akurat berdasarkan hasil dari penelitian.

Metodelogi merupakan suatu cara yang digunakan dalam penelitian dengan maksud mencari sesuatu hal dengan logika berfikir seksama untuk mencapai suatu tujuan melalui pengetahuan, berdasarkan hal dapat diambil kesimpulan bahwa penelitian menggunakan metode dekriptif adalah cabang ilmu pengetahuan penelitian berdasarkan fakta atau gejala yang diteliti, pengertian motede deskriptif dikemukakan oleh Suharsimi Arikunto (1993:25) yang menyatakan “apabila peneliti bertujuan untuk dapat mengetahui keadaan sesuatu mengenai apa dan bagaimana, berapa banyak, sejauh mana dan sebagainya, diperlukan penelitian yang bersifat deskriptif, yaitu menjelaskan atau menerangkan peristiwa".

Berdasarkan penjelaskan di atas peneliti beralasan penggunaan motede dekriptif ini adalah untuk menjelaskan bagaimana implementasi pembelajaran berbasis Student Centered Learning (SCL. (Studi Deskriptif di Jurusan Pendidikan Pancsila dan Kewarganegaraan Fakultas Keguruan dan Ilmu Pendidikan Universitas Sultan Ageng Tirtayasa).

\section{HASIL PENELITIAN \\ PEMBAHASAN}

DAN

1. Implementasi Pembelajaran Berbasis Student Centered Learning (SCL)di Jurusan Pendikan Pancasila dan Kewarganegaraan Jurusan Pendidikan Pancasila dan Kewarganegaran adalah jurusan yang mengedepankan kualitas pembelajaran, hal tersebut bertujuan untuk dapat memaksimalkan kompetensi yang akan diterima oleh mahasiswa, untuk mencapai hal tersebut jurusan Pendidikan Pancasila dan Kewarganegaraan berkomitmen dalam proses perkuliahannya menerapakan proses pembelajaran yang bermutu dengan mengutamakan kreatifitas, keaktifan mahasiswa hal tersebut di implementasikan melalui pembelajaran yang berbasis Student Centered Learning (SCL), dengan kreatifitas dan keaktifan menjadikan mahasiswa menjadi pusat dalam proses perkuliahan, dimana mahasiswa dituntut tidak selalu 
ketergantungan terhadap dosen pengampu mata kuliah, mahasiswa dapat belajar dari berbagai sumber belajar, ataupun bahan ajar yang dapat dijadikan sebagai pengetahuan dalam pembelajaran, sumber belajar di jurusan Pendidikan Pancasila dan Kewarganegaraan dapat diambil dari berbagai sumber baik buku, internet, lingkungan baik di kampus maupun di luar kampus yang dapat dijadikan laboratorium untuk proses pembelajaran, di jurusan Pendidikan Pancasila dan Kewarganegaraan sumber belajar sangatlah luas, dalam penerepan pembelajaran berbasis Student Centered Learning (SCL)dosen berperan sebagai mitra belajar bukan sebagai unsur satu-satunya belajar, keaktifan belajar menuntut mahasiswa untuk berperan aktif mengaktulisasikan diri dalam proses pembelajaran, tidak hanya mendengarkan penjelasan dari dosen tapi berperan serta dalam proses pembelajaran dengan cara aktif bertanya, aktif menyampaikan pendapat sehingga pemahaman materi dan kompetensi yang ingin dicapat dapat terlasana dengan baik.

Melalui penerapan pendekatan pembelajaran berbasis Student Centered Learning (SCL) mampu menjadikan mahasiswa lebih aktif dan kreatif dalam proses perkuliahan yang berlangsung dan malatih unsur-unsur kemandirian mahasiswa dalam proses pembelajaran, penerapan ketepatan pendekatan pembelajaran yang berpusat di mahasiswa pada akhirnya dapat meningkatkan kompetensi mahasiswa, hal ini dikarenakan dalam proses pembelajaran yang menggunakan Student Centered Learning (SCL) porsi keaktifan dosen dan mahasiswa, lebih banyak berperan aktif mahasiswa dalam proses pembelajaran ketika berlangsung, dan selain penggunaan model pemebelajaran, metode pembelajaran, bahan ajar, media pembelajaran, cenderung jauh lebih dapat dimanfaatkan oleh mahasiswa dalam kegiatan pembelajaran.

Dari analisis data mengenai perkuliahan yang berbasis pendekatan Student Centered Learning (SCL) menunjukkan bahwa penerapan pendekatan pembelajaran yang berpusat pada mahasiswa terlihat dalam langkah-langkah pembelajaran, hal ini ditunjukkan pada tahapan perencanaan pembelajaran yang menggunakan rencana pembelajaran semester (RPS) yang mencantumkan proses perkuliahan menggunakan pendekatan Student Centered Learning (SCL), dalam penyususnan RPS jurusan Pendidikan Pancasila dan Kewarganegaran menerapkan standarisasi dalam pembuatan RPS, hal tersebut bertujuan untuk dapat mencapai kompetensi yang igin dicapai, di dalam RPS terdapat identitas matakuliah, deskripsi matakuliah, capaian pembelajaran jurusan, capaian pembelajaran mata kuliah, dan deskripsi rencana pembelajaran. 
Identitas mata kuliah ini memuat data-data tentang perkuliahan, dalam deskripsi mata kuliah memuat pembahasan mata kuliah, capaian pembelajaran jurusan bagaiman mahasiswa dapat menerapkan hasil dari pembelajaran, capaian pembelajaran merupakan kompetensi yang ingin dicapai, dan dalam deskripsi rencana pembelajaran terdapat indikator capaian pembelajaran matakuliah, bahan kajian, bentuk pembelajaran, waktu, tugas dan penilaian, yang di dalamya tercantunm menggunakan Student Centered Learning (SCL).

Dibuatnya RPS ini sebagai bentuk perencanaan dosen sebelum melaksanakan pembelajaran dan evalusi pembelajaran, karena dengan perencanaan pembelajaran yang baik diharapkan dapat merencanakan langah-langkah pembelajaran dengan baik dan banar, sehingga kompetensi yang ingin dicapai dapat terlaksana.

Selain membuat RPS sebagai bentuk perencanaan pembelajaran dosen mempersiapkan ha- hal lainnya seperti bahan ajar, media pembelajaran, yang akan akan dijadikan sebagai sumber belajar, bahan ajar yang yang disiapkan disesuaikan dengan materi pembelajaran yang akan dibahas, tujuan disiapkannya bahan ajar agar mahasiswa mendapatkan pengetahuan lebih sesuai dengan kebutuhan pembelajaran, media pembelajaran digunakan sebagai alat bantu proses perkuliahan dengan tujuan mempermudah dalam proses perkuliahan, untuk dapat mengefisiensikan pembelajaran, menjaga relevansi perkuliahan, dan memfokuskan materi pembelajaran.

Perencanaan pembelajaran ini dibuat sebelum melakukan tahap selanjunya yaitu pelaksanaan pembelajaran, dan dalam penyususuan perencanaan pembelajaran mengutamakan sasaran tujuan kompetensi melalui pendekatan pembelajaran Student Centered Learning (SCL)karena pada prinsipnya ketika perencanaan pembelajaran terlaksana dengan baik maka setengah keberhasilan pembelajaran sudah tercapai.

Setelah tahap perencanaan selesai dilakukan langkah selanjunya yaitu tahap pelaksanaan pembelajaran, dalam tahap ini dilaksanakan berdasarkan RPS yang telah dibuat yang dipraktikan pada tahap pelaksanaan pembelajaran, dalam tahap pembelajaran ini dosen melakukan beberapa langkah kegiatan pendahualuan, kegitan inti dan kegiatan penutup.

Kegiatan pendahuluan pembelajaran merupakan tahapan pertama dalam proses pembelajaran kegiatan ini juga sering disebut dengan kegiatan pra instruksional, kegiatan pendahualan berfungsi sebagai mengefektifkan den mengefesiensikan waktu pembelajaran, dalam kegiatan pendahuluan atau dikenal juga sebagai pra instruksional seorang dosen harus mempersiapkan pelaksanaan pembelajaran dengan cara mengkondisikan mahasiswa baik secara psikis dan fisik untuk mengikuti jalannya 
proses pembelajaran, hal ini bertujaan agar proses pembelajaran dapat berjalan dengan baik, setelah itu langkah selanjunya yaitu memotivasi mahasiswa untuk dapat menerima materi dengan baik, dosen mengajukan beberapa pertayaan yang bertujuan untuk mengaitkan dengan materi sebelumnya yang telah dipelajari, menjelaskan tujuan pembelajaran atau yang berkaitan kompetensi yang ingin dicapai dalam pembelajaran, dan menyampaikan cakupan materi serta penjelasan susunan kegiatan pembelajaran sesuai dengan RPS yang telah dibuat. Berdasarkan hal tersebut pelaksanaan kegiatan pendahuluan yangdilakukukan bertujuan untuk dapat mengefektikan kondisi ketika memasuki kegitian inti dalam proses pembelajaran.

Setelah melakukan kegiatan pendahuluan langkah selanjutnya yaitu melaksanakan kegiatan inti dalam kegiatan inti ini peran dosen dalam pembelajaran tidak dominan dikarenakan ingin mengutamakan dominasi dalam proses perkuliahan dikegiatan inti lebih didomnasi oleh mahasiswa sebagai bentuk pembelajaran yang menggunakan pendekatan pembelajaran Student Centered Learning (SCL) yang menuntut mahasiswa untuk berperan seaktif dan sekretif mungkin dalam pembelajaran. Dalam kegiatan inti langkah pertama adalah dosen menjelaskan materi perkuliahan dengan durasi waktu yang telah disesuikan untuk penjelasan materi, setelah penjelasan meteri pembelajaran selesai disampaikan, maka porsi dari pembelajaran akan di dominasi oleh mahasiswa dengan durasi waktu yang lebih lama di bandingkan dosen, beberapa kegiatan yang memberikan peluang kretifitas dan keaktifan mahasiswa sebagai bentuk Student Centered Learning (SCL) yaitu melalui pemberikan kebebasan mahasiswa untuk melakukan pengamatan melului media yang telah disipakan oleh dosen sebagai bahan ajar yang disampaikan pada penjelasan yang telah disampaikan oleh dosen, dimana mahasiswa harus dapat fokus untuk dapat memahami materi yang telah disampaikan. Atau dapat juga mengamati sesuai dengan objek yang sesuai dengan materi pembelajaran yang diajarkan baik yang di samapaikan oleh dosen atau berdasarkan sumber lain yang sesuai dengan materi pembelajaran.

Setalah tahap mengamati selesai dilakukan mahasiswa diberikan kesempatan yang seluas luasnya untuk dapat menyampaikan pertanyaan-pertayaan atau juga menyampaikan pendapatnya seputar materi perkuliahan, dalam hal ini mahasiswa dituntut untuk seaktif mungkin dalam memahi materi baik untuk menyampaikan pertanyaan atau menanggapi yang berkaiatan penjelasan meteri, untuk proses mengamati diperlukan berbagai sumber materi pembelajaran baik yang ada di kelas maupun di luar kelas sebagai sumber pembelajaran.

Dalam pelaksanaan kegiatan inti proses pembelajaran menggunakan media 
pembelajaran hampir setiap pertemuan selalu digunakan guna menunjang peningkatan kompetensi mahasiswa diamana mahasiswa dituntut untuk dapat membuat slide power point yang berisi materi-meteri yang ditugaskan berdasarkan berbagai sumber belajar sebagai bentuk implementasi pendekatan pembelajaran berbasis Student Centered Learning (SCL), mahasiswa ditugaskan secara berkelompok untuk membuat media pembelajaran baik slide power point atau media pembelajaran lainnya yang berisi penjejelasan materi yang ditugaskan sesuai dengan kelompoknya masing-masing, dalam pembuatan slide power point atau media pembelajaran lainnya mahasiswa dituntut untuk dapat menyajikan materi dengan seditail dan semenarik mungkin, setelah pembuatan slide power point atau media pembelajaran selesai mahasiswa harus dapat mempresentasikannya di dapan kelas, dan setelah selesai dipresntasikan langkah selanjutnya adalah proses tanya jawab seputar materi yang dipresentasikan atau menaggapi seputar materi yang dipresentasikan.

Pelaksanaan pembelajaran yang berbasis Student Centered Learning (SCL) dilakukan di jurusan Pendidikan Pancasila dan Kewarganegaraan menekankan prinsipprinsip yang harus dimengerti dan dijalankan yaitu harus mempu bertanggung jawab dalam pembelajaran, mahasiswa harus dapat berperan serta dan aktif dalam proses pembelajaran, menerapkan prinsip keadilan bahwa dalam proses pembelajaran, setiap individu mahasiswa memilki hak yang sama, prinsip mandiri mahasiswa sebagai pelaku utama dalam proses pembelajaran dan dosen berperan sebagai mitra dalam proses pembelajaran, mahasiswa dituntut untuk dapat berfikir kritis dan kereatif berkaitan dengan materi perkuliahan, prinsip komunikatif dibutuhkan untuk menentukan persepsi yang berkaitan dengan materi pembelajaran, prinsip kerja sama dimana siap individu mahasiswa harus dapat bekerja sama untuk mencapai kompetensi atau keberhasilan pembelajaran, dan yang teraktik adalah prinsip integritas sebagai bentuk konsistensi dan karakter yang kuat untuk dapat melaksanakan pembelajaran dengan baik.

Pelaksanaan pembelajaran yang berbasis Student Centered Learning (SCL) yang diterapkan di jurusan Pendidikan Pancasila dan Kewarganegaraan selain yang dijelaskan di atas, juga menerapkan pembelajaran yang mengunakan e-learning, pengunaan $e$ learning di jurusan Pendidikan Pancasila dan Kewarganegaraan sebagai bentuk tuntutan kemajuan teknologi, sehingga jurusan melihat peluang dalam menggunakan pembelajaran yang berbasis teknologi, penggunaan e-learning ini dapat menjadikan sumber belajar lebih beragam hal ini memungkinkan keaktifan mahasiswa untuk dapat mencari sumber belajar yang lebih 
beragam, proses pembelajaran dapat dilaksanakan dimanapun dan kapanun, dengan waktu yang cenderung lebih fleksibel sehingga mahasiswa mempunyai kendali sepenuhnya untuk dapat mengatur pola pembelajarannya, dengan penggunaan $e$ learning dapat menentukan belajar sesuai dengan kemampuan individu, karena setiap individu memiliki kempuan belajarnya masing-masing. Diharapkan dengan adanya pembelajaran menggunakan e-learning sebagai bentuk pembelajaran berbasis Student Centered Learning (SCL) dapat meningkatkan kompetensi pembelajaran, Pelaksanan pembelajaran berbasis Student Centered Learning (SCL) ini menempatkan mahasiswa sebagai pusat dari proses pembelajaran karena mahasiswa menjadi objek dan subjek dalam pembelajaran mahasiswa dituntut berperan aktif dan kreatif, sehingga dapat menjadikan kegiatan pembelajaran yang mandiri.

Kegiatan penutup dalam pembelajaran dosen bersama-sama dengan mahasiswa membuat rangkuman atau suatu kesimpulan pembelajaran, melakukan penilaian atau refleksi terhadap pelaksanaan pembelajaran yang telah dilaksanakan, memberikan umpan balik tentang proses dan hasil pembelajaran, melakukan kegiatan tindak lanjut dalam bentuk tugas yang diberika kepada mahasiswa baik tugas secara kelompok maupun tugas secara individu, dan menginformasikan materi pembahasan untuk pertemuan selanjutnya, dengan tujuan agar mahasiswa dapat mempersiapkan untuk mempelajari secara individu meteri selanjutnya, kegiatan penutup pembelajaran merupakan suatu kegiatan yang penting untuk dilakukan agar dapat mengukur tingkat keberhasilan pembelajaran, untuk dapat mengetahui apakah proses peembelajaran sudah dilaksanakan dengan baik dan benar.

1. Kendala Pendekatan Pembelajaran Berbasis Student Centered Learning (SCL)

Adapun beberapa kendala yang dialami dosen dan mahasiswa dalam proses penerapan pendekatan pembelajaran Student Centered Learning (SCL) yaitu masih ditemukan beberapa mahasiswa yang minat bertanya masih kurang, meskipun sudah memahami materi yang telah disampaikan sebelumnya tetapi dalam merumuskan pertanyaan mahasiswa masih perlu diberikan bimbingan dan dorongan, hal ini disebabkan masih banyak mahasiswa yang merasa enggan bahkan malu apabila salah dalam bertanya, selain itu keinginan dalam mencari referensi dan sumber bacaan lain masih kurang sehingga mengakibatkan mahasiswa yang terus-menerus terpaku dan bergantung secara penuh pada dosen, kendala lainnya yaitu pada saat mengumpulkan data dan mengolah informasi masih ada mahasiswa yang enggan bekerja sama serta hanya menunggu hasil pekerjaan teman sekelompoknya. dalam penerapan pendekatan pembelajaran Student Centered 
Learning (SCL) ini tidak semua kemampuaan mahasiswa dapat tersalurkan melalui pendekatan Student Centered Learning (SCL) ini, karena masih banyak mahasiswa yang cenderung dengan karakteristiknya yang pendiam sulit untuk dapat memperaktekan menyeluruh pola pembelajaran pendekatan Student Centered Learning (SCL) ini.

Dalam proses pembelajaran berbasis Student Centered Learning (SCL)menuntut mahasiswa seaktif mungkin untuk belajar sehingga membuat suasana kelas cenderung ramai, maka diperlukan keadaan kondisi kelas yang jauh lebih luas, dan kedap suara sehingga tidak mengganggu proses perkulihan di kelas yang bersampingan, karena dalam proses pendekatan pembelajaran Student Centered Learning (SCL) sering dilakukan kegiatan diskusi dalam materi pembelajaran.

Berdasarkan pemaparan di atas masih banyak ditemukan kendala-kendala dalam pendekatan pembelajaran berbasis Student Centered Learning (SCL), dosen harus dapat meminimalisir segela bentuk kekurangan yang ada, karena dosen selain menjadi fasilitator dosen juga harus dapat berperan sebagai pengelola kelas dengan tepat, berdasarkan hal tersebut dapat diambil kesimpulan bahwa pelaksanaan pembelajaran akan berjalan dengan baik dan benar salah satunya dipengaruhi kemampuan dosen sebagai pengelola kelas dengan baik,
2. Solusi Menghadapi Kendala Pendekatan Pembelajaran Berbasis Student Centered Learning (SCL)

Pentingnya peran dosen dalam melakukan berbagai upaya untuk mengatasi berbagai kendala dengan cara memberikan motivasi kepada mahasiswa untuk dapat bertanya atau mengemukakan pendapat mereka, untuk mengatasi keterbatasan referensi maka mahasiswa dapat diarahkan untuk mencari sumber belajar lain di perpustakaan maupun melalui internet terkait materi perkuliahan sehingga mahasiswa mampu mengetahui dan mengakses beragam informasi aktual sebagai bahan untuk menambah dan mengembangkan wawasan dalam materi perkuliahan, keadaan luas kondisi kelas atau ruang perkuliahan sebaiknya disesuaikan dengan jumlah mahasiswa yang mengontrak mata kuliah, dan kondisi ruangan harus seefektif mungkin untuk menunjang proses pembelajaran dengan menggunakan pendekatan pembelajaran Student Centered Learning (SCL).

Berdasarkan solusi yang disampaikan di atas diharapkan dapat lebih meningkatkan kualitas pembelajaran khusnya proses pembelajaran menggunakan pendekatan berbasis Student Centered Learning (SCL)yang pada akhirnya dapat meningkatkan kompetensi dari tujuan pembelajaran. 


\section{KESIMPULAN}

Berdasarkan hasil pembahasan penelitian ini dapat disimpulkan bahwa jurusan Pendidikan Pancasila dan Kewarganegaraan sudah menerapkan pendekatan pembelajaran yang berbasis Student Centered Learning (SCL), dalam proses implementasi pembelajaran dilakukan beberapa tahap, yaitu diantaranya tahap perencanaan, tahap pelaksanaan, dan tahap evaluasi.

Dalam tahap kegiatan perencanaan pembelajaran dosen menyiapkan administrasi pembelajaran diantaranya membuat RPS, dan mempersiapkan hal-hal yang menunjang dalam proses pembelajaran yaitu seperti media pembelajaran, sumber belajar, ataupun inovasi pembelajaran lainnya, tahap perencanaan pembelajaran ini bertujuan untuk menentukan langkah awal agar proses pembelajaran dapat berjalan dengan efektif dan efisien, pembuatan perencaan pembelajaran yang dibuat untuk bagaimana memposisikan peran mahasiswa lebih dominan di bandingkan peran dosen sebagai bentuk pembelajaran yang berbasis Student Centered Learning (SCL), apabila proses perencanaan pembelajaran dilaksanakan dengan baik maka langkah selanjunya pelaksanaan dan evalusi akan berdampak baik terhadap hasil belajar. Tahap selanjunya yaitu tahap kegiatan pelaksanan pembelajaran dalam tahap ini yang paling berperan bagaimana mahasiswa dapat mengimplementasikan pembelajaran berbasis
Student Centered Learning (SCL), dalam tahap ini pelaksanaan pembelajaran lebih berperan mahasiswa di bandingkan dengan dosen, mahasiswa dituntut untuk dapat aktif dan kreatif dalam proses pembelajaran, dalam kegiatan inti penggunaan media pembelajaran sangat membantu untuk dapat mengimplementasikan pembelajaran yang berpusat di mahasiswa, peran aktif mahasiswa dapat diterapkan melalui presentasi di depan kelas tentang materi yang sedang dibahas, selain itu penggunaan pembelajaran yang berbasis elektronik atau $e$ learning sudah diterapkan di jurusan Pendidikan Pancasila dan Kewarganegaraan, tahap terakhir adalah kegiatan penutup dalam kegiatan ini hal yang biasa dilakukan melakukan refleksi pembelajaran yang bertujuan untuk bagaimana mengevaluasi untuk menentukan perbaikan pemebelajaran pada pertemuan selanjutnya.

Kendala yang dialami dalam pelaksanaan pembelajaran yang berbasis Student Centered Learning (SCL) adalah masih ditemukanya beberapa mahasiswa yang cenderung pendiam tidak begitu aktif dalam proses pembelajaran, dan masih ada beberapa mahasiswa yang cenderung individual, kurang dapat bekerjasama apabila ada kegiatan diskusi kelompok, kendala selanjutnya yaitu masih terdapat kondisi ruang kelas yang kurang luas dan terdapat kelas yang kurang kedap suara karena dalam 
proses pembelajaran yang berbasis Student Centered Learning (SCL) sering dilakukan diskusi atau prensentasi materi dihawatirkan dapat mengganggu kegiatan proses pembelajaran yang sedang berlangsung di kelas yang bersebelahan.

Solusi yang diterapkan yaitu dosen harus lebih dapat memotivasi mahasiswa agar lebih berperan aktif dalam kegitan pelaksanaan pembelajaran dan dibutuhkan kondisi ruangngan kelas yang lebih kondusip untuk menunjang proses pembelajaran sehingga kompetensi yang ingin dicapai dalam pembelajaran dapat terlaksana dengan baik.

\section{DAFTAR PUSTAKA}

\section{Buku}

Arikunto, Suharsimi. (1993). Menejemen Penelitian. Jakarta: PT. Raja Grafindo.

Hesson, M., and Shad, K.F. 2007. A StudentCentered Learning Model. AmericanJournalof Applied Sciences. 4 (9), 628-636.

Moleong, Lexy J. (2005), Metodologi Penelitian Kualitatif. Bandung : PT Remaja Rosdakarya.

Rochman Natawiyaja. (2005). Aktivitas Belajar. Jakarta : Depdiknas

\section{Perundang-Undangan}

Undang-Undang RI No 14 Tahun 2005

tentang Guru dan Dosen

Undang-Undang RI No 20 Tahun 2003

tentang Sistem Pendidikan Nasional 